\title{
Long survival sporadic Creutzfeldt-Jakob disease
}

Xiao-Ying Liu, MD, PhD, Qi Shi, PhD, and Gang Wang, MD, PhD

Neurology ${ }^{\circledR}$ 2020;95:87-88. doi:10.1212/WNL.0000000000009793

Figure Sequential diffusion-weighted imaging changes
October 2017
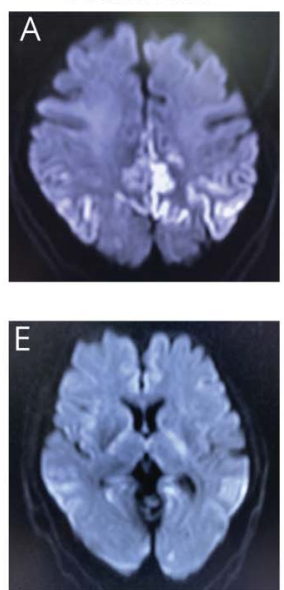

May 2018
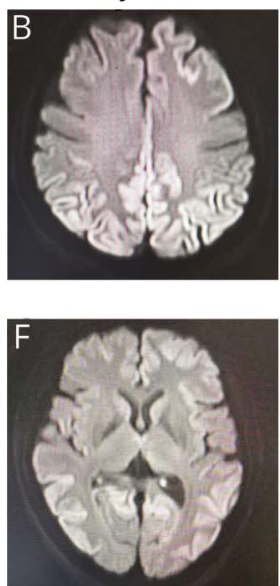

March 2019
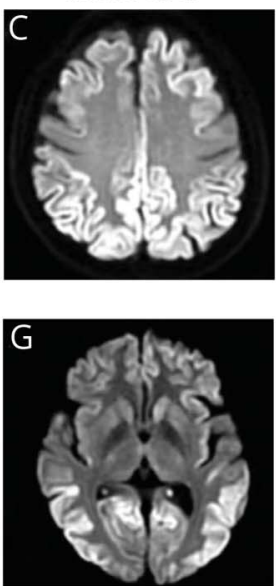

June 2019
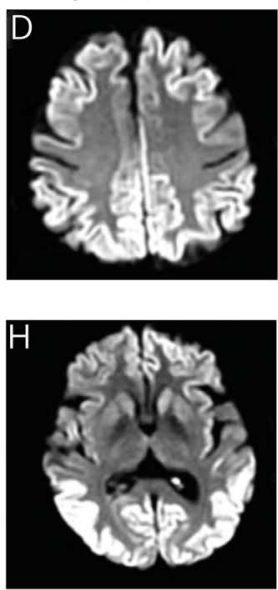

I. Signal curve(s)

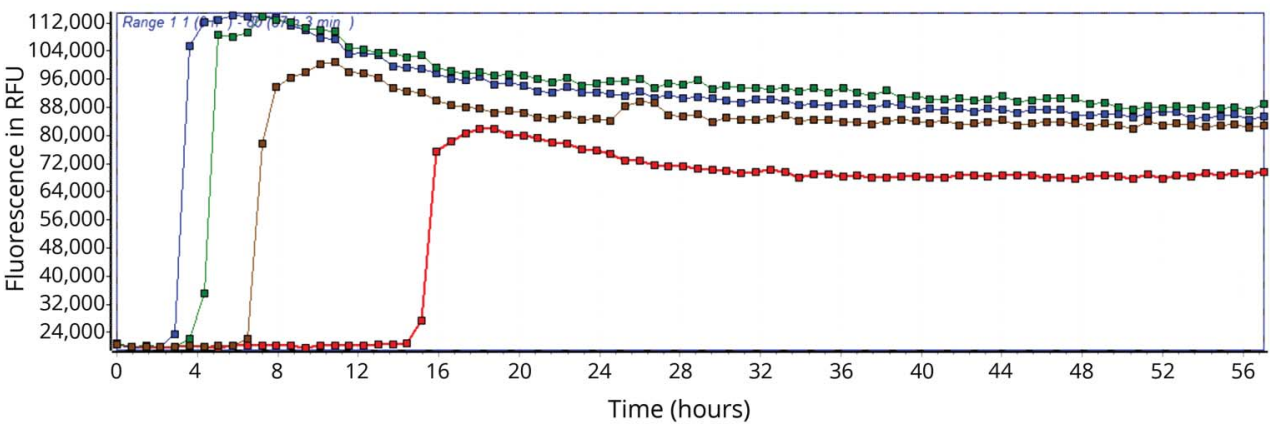

Transverse scans through the lower part of paracentral lobe (A-D) and the basal ganglia (E-H) at different periods after disease onset are shown. Hyperintensities were initially constrained to the posterior parietal lobe, and extended to the anterior parietal lobe. (I) Real-time quaking-induced conversion for detection of prion: positive in 4 duplicate wells.

A 63-year-old woman had slowly progressive dementia. EEG displayed periodic sharp wave complexes. MRI showed cortical ribbon pattern in cortex and hyperintensity in basal ganglia (figure, A-H). Genetics testing confirmed homozygosity for methionine at the polymorphic codon 129 of the PRNP gene. At 34 months after disease onset, she was alive and had not reached akinetic mutism. Skin prions were positive by real-time quaking-induced conversion assays (figure, I). This case demonstrates a rare long-survival sporadic Creutzfeldt-Jakob disease case that is contradictory to traditional duration of illness and the utility of minimally invasive skin biopsy testing for antemortem confirmation. ${ }^{1,2}$

\author{
Correspondence \\ Dr. Wang \\ wg11424@rjh.com.cn
}




\section{Acknowledgment}

The authors thank Prof. Allan Levey, School of Medicine, Emory University, Atlanta, GA, for critical reading and comments on this case.

\section{Study funding}

This work was supported by grants from the Shanghai $\mathrm{Mu}-$ nicipal Education Commission-Gaofeng Clinical Medicine Grant Support (20172001) and Shanghai "Rising Stars of Medical Talent" Youth Development Program-Outstanding Youth Medical Talents (2018).

\section{Disclosure}

The authors report no disclosures relevant to the manuscript. Go to Neurology.org/N for full disclosures.

\section{Appendix Authors}

\begin{tabular}{|c|c|c|}
\hline Name & Location & Contribution \\
\hline $\begin{array}{l}\text { Xiao- } \\
\text { Ying Liu, } \\
\text { MD, PhD }\end{array}$ & $\begin{array}{l}\text { Department of Neurology, } \\
\text { Ruijin Hospital, Shanghai } \\
\text { Jiaotong University School of } \\
\text { Medicine, Shanghai, China }\end{array}$ & $\begin{array}{l}\text { Drafting/revising the } \\
\text { manuscript, analysis or } \\
\text { interpretation of data, } \\
\text { acquisition of data }\end{array}$ \\
\hline
\end{tabular}

\begin{tabular}{|c|c|c|}
\hline Name & Location & Contribution \\
\hline $\begin{array}{l}\text { Qi Shi, } \\
\text { PhD }\end{array}$ & $\begin{array}{l}\text { National Institute for Viral } \\
\text { Disease Control and } \\
\text { Prevention, Chinese } \\
\text { Center for Disease Control } \\
\text { and Prevention, Beijing, } \\
\text { China }\end{array}$ & $\begin{array}{l}\text { Analysis or interpretation of } \\
\text { data, acquisition of data }\end{array}$ \\
\hline $\begin{array}{l}\text { Gang } \\
\text { Wang, } \\
\text { MD, PhD }\end{array}$ & $\begin{array}{l}\text { Department of Neurology, } \\
\text { Ruijin Hospital, Shanghai } \\
\text { Jiaotong University School of } \\
\text { Medicine, Shanghai, China }\end{array}$ & $\begin{array}{l}\text { Drafting/revising the } \\
\text { manuscript, study concept } \\
\text { or design, analysis or } \\
\text { interpretation of data, } \\
\text { acquisition of data, study } \\
\text { supervision }\end{array}$ \\
\hline
\end{tabular}

\section{References}

1. D'Arcy CE, Bitnun A, Coulthart MB, et al. Sporadic Creutzfeldt-Jakob disease in a young girl with unusually long survival. J Neuropathol Exp Neurol 2019;78: 373-378.

2. Manix M, Kalakoti P, Henry M, et al. Creutzfeldt-Jakob disease: updated diagnostic criteria, treatment algorithm, and the utility of brain biopsy. Neurosurg Focus 2015; 39:E2.

\section{Get NeuroReady!}

Preparing for the neurology boards? Up for recertification? Or just looking for a comprehensive review and update in neurology? Get ready with the AAN's convenient online courses_now with new names! Choose from NeuroReady: Board Prep Edition or NeuroReady: Continuing Certification Edition and get ready to review, self-assess, and succeed. Visit AAN.com/NeuroReady.

\section{Visit the Neurology ${ }^{\circledast}$ Website at Neurology.org/N}

- More article-based content on home pages

- Streamlined menus and navigation

- Enhanced blog sections for specialty areas

- Same experience on desktop, tablet, and mobile devices

- Improved article reading experience; links more evident (pdf, analytics, social media)

- Neurology ${ }^{\circledR}$ Clinical Practice initiative "Practice Current" global surveys will be accessible across sites

f Find Neurology ${ }^{\circledR}$ on Facebook: http://tinyurl.com/neurologyfan

Follow Neurology ${ }^{\circledR}$ on Twitter: https://twitter.com/GreenJournal 


\title{
Neurology
}

\author{
Long survival sporadic Creutzfeldt-Jakob disease \\ Xiao-Ying Liu, Qi Shi and Gang Wang \\ Neurology 2020;95;87-88 Published Online before print June 10, 2020 \\ DOI 10.1212/WNL.0000000000009793
}

This information is current as of June 10, 2020

$\begin{array}{ll}\begin{array}{l}\text { Updated Information \& } \\ \text { Services }\end{array} & \begin{array}{l}\text { including high resolution figures, can be found at: } \\ \text { http://n.neurology.org/content/95/2/87.full }\end{array} \\ \text { References } & \text { This article cites } 2 \text { articles, } 0 \text { of which you can access for free at: } \\ & \text { http://n.neurology.org/content/95/2/87.full\#ref-list-1 } \\ \text { Subspecialty Collections } & \text { This article, along with others on similar topics, appears in the } \\ & \text { following collection(s): } \\ & \text { Autoimmune diseases } \\ \text { http://n.neurology.org/cgi/collection/autoimmune_diseases } & \\ & \text { EEG; see Epilepsy/Seizures } \\ \text { http://n.neurology.org/cgi/collection/eeg_see_epilepsy-seizures } & \text { Prion disease; see Infections/prion } \\ & \text { http://n.neurology.org/cgi/collection/prion_disease } \\ & \text { Information about reproducing this article in parts (figures,tables) or in } \\ & \text { its entirety can be found online at: } \\ \text { http://www.neurology.org/about/about_the_journal\#permissions } & \text { Information about ordering reprints can be found online: } \\ \text { Permissions \& Licensing } & \text { http://n.neurology.org/subscribers/advertise }\end{array}$

Neurology ${ }^{\circledR}$ is the official journal of the American Academy of Neurology. Published continuously since 1951, it is now a weekly with 48 issues per year. Copyright (C 2020 American Academy of Neurology. All rights reserved. Print ISSN: 0028-3878. Online ISSN: 1526-632X.

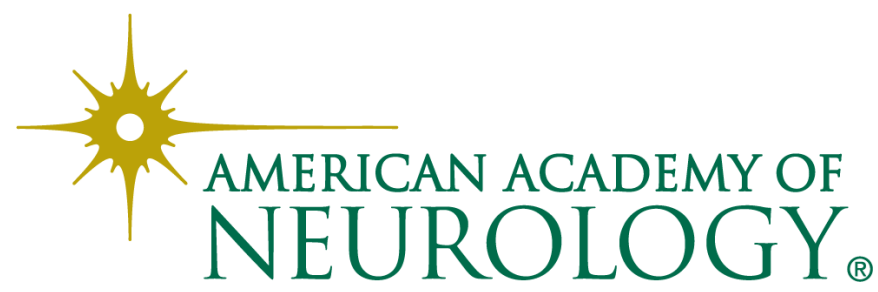

